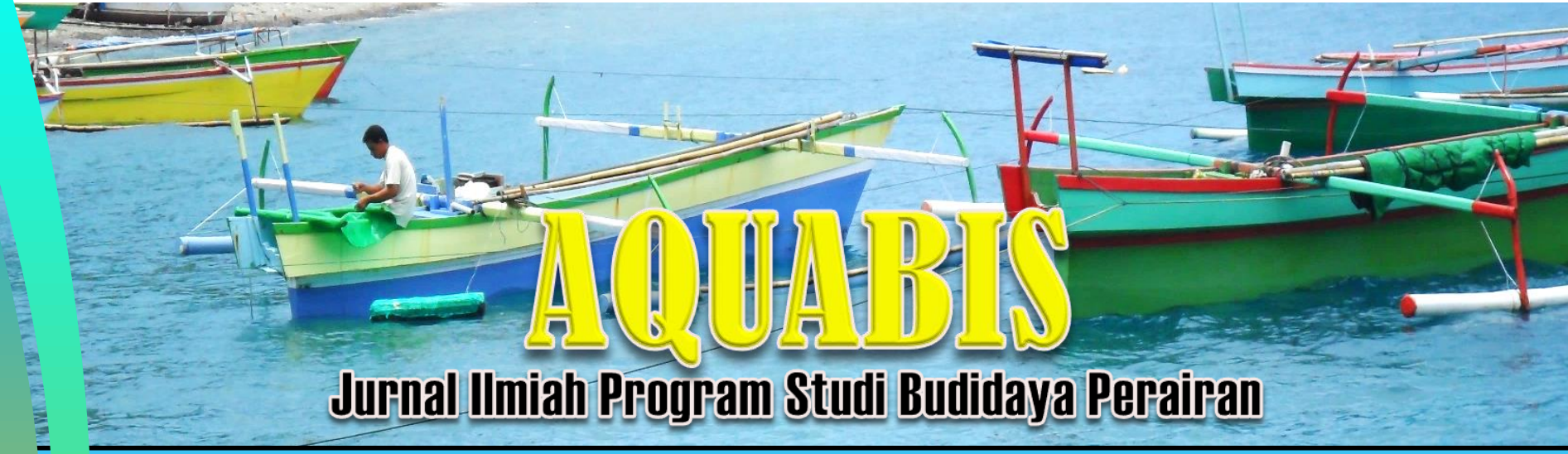

Volume 7 Nomor 2 Desember 2017

ISSN: 2301-5705

SANITASI DAN HYGIENE PADA PROSES PEMBUATAN RAMBAK IKAN BUNTAL PISANG (Tetraodon lunaris) DI UKM JAYA UTAMA KECAMATAN MAYANGAN KOTA PROBOLINGGO JAWA TIMUR

Rahyuni Syamsudin Domili 1

NILAI MANFAAT LANGSUNG EKOSISTEM TERUMBU KARANG DI TAMAN WISATA PERAIRAN PADAIDO, PAPUA

Ni'mawati Syariah 7

STRUKTUR KOMUNITAS MAKROZOOBENTOS PADA EKOSISTEM PADANG LAMUN DI PERAIRAN PANTAI LOGPON DESA MOLANTADU KABUPATEN GORONTALO UTARA.

Nurul Auliyah, Candra Masuara 13

TINGKAT KESUKAAN DAN KADAR PROTEIN ILABULO CUMI-CUMI YANG BERSUBTITUSI TEPUNG TAPIOKA

Yulianti

REHABILITASI LAHAN MANGROVE OLEH MASYARAKAT PESISIR DI DAS RANDANGAN KABUPATEN POHUWATO

Dewa Oka Suparwata

PEMBERIAN DOSIS PAKAN OTOHIME YANG BERBEDA TERHADAP PERTUMBUHAN BENIH IKAN KERAPU BEBEK (Chromileptes altivelis)

Erlansyah, Hasim, dan Mulis 33

PENGARUH PERTUMBUHAN DAN EFISIENSI PAKAN IKAN NILA GIFT (Oreochromis niloticus) DENGAN PROPORSI PROTEIN PAKAN YANG BERBEDA

Titin Liana Febriyanti 39 


\title{
PEMBERIAN DOSIS PAKAN OTOHIME YANG BERBEDA TERHADAP PERTUMBUHAN BENIH IKAN KERAPU BEBEK (Chromileptes altivelis)
}

\author{
${ }^{1}$ Erlansyah, ${ }^{2}$ Hasim, dan ${ }^{2}$ Mulis \\ ${ }^{1}$ Jurusan Teknologi Perikanan Fakultas Ilmu-Ilmu Pertanian \\ Universitas Negeri Gorontalo \\ Email: erlansyah@gmail.com
}

\begin{abstract}
This research is aimed to find out the influence of different distribution of otohime fodder dosage toward the growth of humpback grouper seeds. This research used RAL (complete randomized design) with three treatments and 3 repetition. Animal test used is the seeds of humpback grouper sized 3,0 cm, weigh 0,38-0,39 grams, as many as 90 seeds. The fodder given is otohime fodder. The feeding is done 3 times a day. The treatment tested is the difference of the distribution of the dosage which is 5\%,10\%, and 15\% from the biomass total of the seeds. Weighing and measuring is done once a week. The 10\% dosage produces optimum growth of the seeds with absolute length is $0,59 \mathrm{~cm}$ and absolute weight is at 0,21 gram, then followed by the $15 \%$ dosage with absolute lenght at 0,52 cm and absolute weight at 0,13 gram, and the last is the 5\% dosage with absolute lenght at 0,46 cm and absolute weight at 0,10 gram.
\end{abstract}

Keywords: Humpback grouper, fodder dosage, growth

\begin{abstract}
Abstrak
Penelitian ini bertujuan untuk mengetahui pengaruh pemberian dosis pakan otohime yang berbeda terhadap pertumbuhan benih ikan kerapu bebek (Chromileptes altivelis). Penelitian ini menggunakan Rancangan Acak Lengkap (RAL) dengan 3 perlakuan dan 3 ulangan. Hewan uji yang digunakan adalah benih ikan kerapu bebek ukuran \pm 3,0 cm, berat 0,38-0,39 gram, sebanyak 90 ekor. Pakan yang diberikan adalah pakan pellet otohime. Pemberian pakan dilakukan tiga kali sehari. Perlakuan yang diujikan adalah perbedaan dosis pakan 5\%, 10\%, dan $15 \%$, dari total biomassa benih. Penimbangan dan pengukuran dilakukan setiap seminggu sekali. Tingkat pemberian dosis pakan $10 \%$, menghasilkan pertumbuhan benih yang optimal dengan panjang mutlak $0,59 \mathrm{~cm}$ dan berat mutlak 0,21 gram, kemudian disusul perlakuan $\mathrm{C}$ dosis $15 \%$ panjang mutlak $0,52 \mathrm{~cm}$ berat mutlak 0,13 gram, dan terendah perlakuan A dosis 5\%, panjang mutlak 0,46 cm berat mutlak 0,10 gram.
\end{abstract}

Kata kunci: Kerapu bebek (chromileptes altivelis), dosis pakan, pertumbuhan

\section{PENDAHULUAN}

Indonesia merupakan negara kepulauan dan $70 \%$ wilayahnya merupakan lautan. Potensi kelautan ini merupakan anugerah yang tak terkira dari Tuhan yang di dalamnya terdapat beraneka sumber daya yang sangat besar yang mampu mensejahterakan masyarakat di sekitarnya. Salah satu potensi yang sangat besar adalah perikanan, khususnya ikan kerapu. Ikan kerapu merupakan salah satu komoditas perikanan yang sangat penting dan mempunyai nilai ekonomis tinggi.

Ikan kerapu bebek (Chromileptes altivelis), merupakan salah satu jenis ikan laut yang mempunyai prospek yang cerah dan layak dikembangkan sebagai ikan budidaya laut karena mempunyai nilai ekonomis yang tinggi di pasar lokal maupun internasional. Ikan kerapu bebek atau kerapu tikus (Chromileptes altivelis), sejenis ikan karang, berprospek cukup cerah karena kelezatan dagingnya. Permintaan terus meningkat, baik untuk pasar ekspor maupun lokal. Harga jual pun sangat tinggi, biasa mencapai ratusan ribu rupiah/kilogram. Peluang budidaya terbuka luas karena lahan usaha budidaya cukup tersedia dan keuntungannya besar (Cahyoko, et al., 2009).

Manajemen pakan ikan merupakan salah satu faktor utama untuk sistem budidaya perikanan. Pakan merupakan unsur terpenting dalam menunjang pertumbuhan dan kelangsungan hidup ikan. Pakan buatan adalah 
pakan yang sengaja dibuat dari beberapa jenis bahan baku yang kemudian diproses lebih lanjut sehingga bentuknya berubah dari bentuk aslinya. Pakan buatan disebut juga sebagai compouded feed, prepared diet, dan lebih umum disebut sebagai pakan (feed).

Pakan buatan dapat digunakan, baik sebagai pakan tambahan maupun sebagai pakan pelengkap. Pakan tambahan adalah pakan yang digunakan untuk melengkapi kebutuhan ikan pemeliharaan selain pakan alami. Pakan buatan yang baik adalah pakan yang mengandung gizi yang penting untuk ikan, memiliki rasa yang disukai oleh ikan dan mudah dicerna oleh ikan (Cahyoko, et al., 2009).

Pakan berenergi adalah pakan yang mengandung kalori yang tinggi. Kalori yang tinggi dapat memperbaiki konversi pakan dan pertambahan berat badan ikan kerapu bebek (Chromileptes altivelis). Menurut Cahyoko, et al., (2009), bahwa ikan membutuhkan energi untuk pertumbuhan, aktivitas hidup dan perkembangbiakan. Pemberian pakan pada ikan harus dilakukan seefisien mungkin, yaitu jumlah, kualitas dan sumber bahan pakan harus sesuai dengan kebutuhan ikan, sebab sekitar 60-65\%, biaya produksi merupakan biaya untuk pakan. Oleh karena itu, pemberian pakan harus seefisien mungkin agar keuntungan usaha tani lebih besar. Ikan menggunakan protein sebagai sumber energi yang utama, sumber energi kedua yang digunakan adalah lemak, sedangkan karbohidrat menjadi sumber energi yang ketiga.

Pellet merupakan pakan yang baik untuk pertambahan berat badan pada ikan, khususnya untuk ikan kerapu bebek (Chromileptes altivelis). Bentuk pakan pellet akan lebih efisien dalam menghasilkan berat badan jika dibandingkan dengan pakan dalam bentuk tepung. Pakan bentuk tepung akan banyak yang terbuang sebagai debu (Taufik, 2009). Dosis pemberian pakan harus diberikan seefisien mungkin, agar pakan yang diberikan benarbenar termakan dan tidak ada yang terbuang serta tidak mencemari perairan. Dosis pemberian pakan yang diberikan untuk ikan kerapu bebek (Chromileptes altivelis), berkisar 5-7,5\% dari biomassa untuk jenis pakan ikan rucah. Sedangkan untuk pakan buatan pellet, dosis pakan yang diberikan 3-5\% dari biomassa perhari (Puja, et al., 2001).

Pakan Otohime yaitu pakan yang berbentuk butiran pellet, sama halnya seperti pakan ikan lainnya. Alasan menggunakan pakan Otohime untuk penelitian, yaitu pakan pellet Otohime, pakan yang tidak cepat tenggelam kedasar, pakan yang tidak mudah pecah, air media hidup ikan kerapu tidak cepat kotor, dan pakan pellet otohime pakan yang baik untuk pertumbuhan benih ikan kerapu bebek (Chromileptes altivelis) (Wawancara Widyanto, 2013).

\section{METODE PENELITIAN}

Pelaksanaan penelitian akan dilaksanakan pada bulan Oktober sampai Desember 2013, yang bertempat di Balai Pengembangan Benih Ikan Laut dan Payau (BPBILP) Lamu, Kabupaten Boalemo, Provinsi Gorontalo. Alat yang digunakan dalam penelitian ini adalah wadah yang bervolume 47 liter, timbangan analitik, alat pengukur kualitas air, selang plastik, penggaris, alat tulis menulis, dan kamera. Bahan yang digunakan sebagai penelitian ini adalah benih ikan kerapu bebek sebagai hewan uji, Pakan sebagai pakan benih ikan kerapu bebek, dan air laut sebagai media hidup. Penelitian ini menggunakan Rancangan Acak Lengkap (RAL) dengan 3 perlakuan dan 3 ulangan sehingga jumlah satuan percobaan adalah 9 unit. Penelitian dilakukan dalam lingkungan yang terkontrol. Perlakuan yang diberikan adalah: Perlakuan A (Dosis 5\%), Perlakuan B (Dosis 10\%), dan Perlakuan C (Dosis 15\%).

\section{Variabel yang Diamati \\ Dosis Pakan}

Penelitian yang akan dilakukan yaitu pengaruh pemberian dosis pakan otohime yang berbeda terhadap pertumbuhan benih ikan kerapu bebek (Chromileptes altivelis), penelitian dilakukan tiga kali perlakuan, dan tiga kali ulangan. Dosis pakan yang diberikan $5 \%$, 10\%, dan $15 \%$ dari berat tubuh ikan. Penimbangan dan pengukuran benih ikan kerapu bebek dilakukan setiap seminggu sekali.

\section{Pertumbuhan Mutlak} bebek

Pertumbuhan panjang benih ikan kerapu

$$
\mathrm{L}=\mathrm{Lt}-\mathrm{Lo}
$$


Keterangan:

Lt = Panjang akhir benih ikan kerapu bebek penelitian waktu minggu ke-t

Lo $=$ Panjang awal benih ikan kerapu bebek (cm)

Petumbuhan berat benih ikan kerapu bebek

$$
\mathrm{W}=\mathrm{Wt}-\mathrm{Wo}_{\mathrm{o}}
$$

Keterangan:

$\mathrm{Wt}=$ Berat akhir penelitian waktu minggu ke- $\mathrm{t}$

$\mathrm{Wo}=$ Berat awal ikan kerapu bebek $(\mathrm{g})$

\section{Pertumbuhan Harian}

Perhitungan Pertambahan Berat Harian Rata-rata atau Average Daily Growth (ADG) menurut Cholik, et al., (2005)

$$
\mathrm{ADG}=\frac{W t-W o}{H}
$$

Keterangan:

$\mathrm{Wt}=$ Berat akhir $(\mathrm{g})$

Wo $=$ Berat awal $(\mathrm{g})$

$\mathrm{H}=$ Lama pemeliharaan (hari)

Perhitungan Pertambahan Panjang Harian Rata-rata Average Daily Growth (ADG) menurut Cholik, et al., (2005)

$$
\mathrm{ADG}=\frac{L t-L o}{H}
$$

Keterangan:

$\mathrm{Lt}=$ Panjang akhir $(\mathrm{cm})$

Lo $=$ Panjang awal $(\mathrm{cm})$

$\mathrm{H}=$ Lama pemeliharaan (hari)

\section{Sintasan}

Kelulusan Hidup (SR) adalah persentase jumlah biota yang hidup pada akhir waktu tertentu menurut Cholik (2005)

$$
\mathrm{SR}=\frac{N t}{N o} \times 100 \%
$$

Keterangan:

$\mathrm{Nt}=$ Jumlah benih ikan kerapu bebek akhir penelitian ke-t

No $=$ Jumlah awal benih ikan kerapu bebek

\section{Analisis Data}

Untuk mengetahui hasil adanya pengaruh yang berbeda terhadap pemberian dosis pakan yang berbeda terhadap pertumbuhan benih ikan kerapu bebek (Chromileptes altivelis), maka data yang diperoleh dianalisis ragam menggunakan Rancangan Acak Lengkap (Steel dan Torrie, 1991 dalam Madinawati, 2011) dengan model matematika sebagai berikut:

$$
\mathrm{Yij}=\mu+\tau \mathrm{i}+\sum \mathrm{ij}
$$

Keterangan:

Yij $=$ Pengamatan dari perlakuan ke $\mathrm{i}$ ulangan ke $\mathrm{j}$

$\mu=$ Nilai tengah populasi

$\tau \mathrm{i}=$ Pengaruh perlakuan ke $\mathrm{i}$

$\sum \mathrm{ij}=$ Galat perlakuan ke $\mathrm{i}$ ulangan ke $\mathrm{j}$

$\mathrm{i}=$ Perlakuan

$\mathrm{j}=$ Ulangan

\section{HASIL DAN PEMBAHASAN}

\section{Pertumbuhan Panjang Mutlak Benih Kerapu Bebek (Chromileptes altivelis)}

Hasil pengukuran panjang benih ikan kerapu bebek selama 28 hari pemeliharaan menunjukkan adanya perbedaan antara perlakuan yang menggunakan dosis 5\%, dosis $10 \%$, dan dosis yang $15 \%$ dapat di lihat pada Gambar 1. Dari Gambar 1 menunjukkan bahwa pemberian dosis pakan yang berbeda memberikan pengaruh terhadap pertumbuhan panjang benih ikan kerapu bebek. Hal ini sesuai dengan pendapat Melianawati, dan Suwirya, (2010), rendahnya tingkat pemberian pakan 5\%, menunjukkan bahwa pakan yang diberikan dapat dimanfaatkan seluruhnya untuk pertumbuhan benih sehingga efisiensi pemanfaatan pakannya tinggi. Sebaliknya pakan yang lebih tinggi pada tingkat pemberian pakan $15 \%$, menunjukkan bahwa pakan yang diberikan tidak seluruhnya dimanfaatkan untuk pertumbuhan benih sehingga efisiensi pemanfaatan pakannya juga rendah. Pakan yang tidak termanfaatkan tersebut, selain berpengaruh buruk bagi kualitas air media pemeliharaan benih, juga berpengaruh terhadap tingginya biaya operasional pemeliharaan benih. 

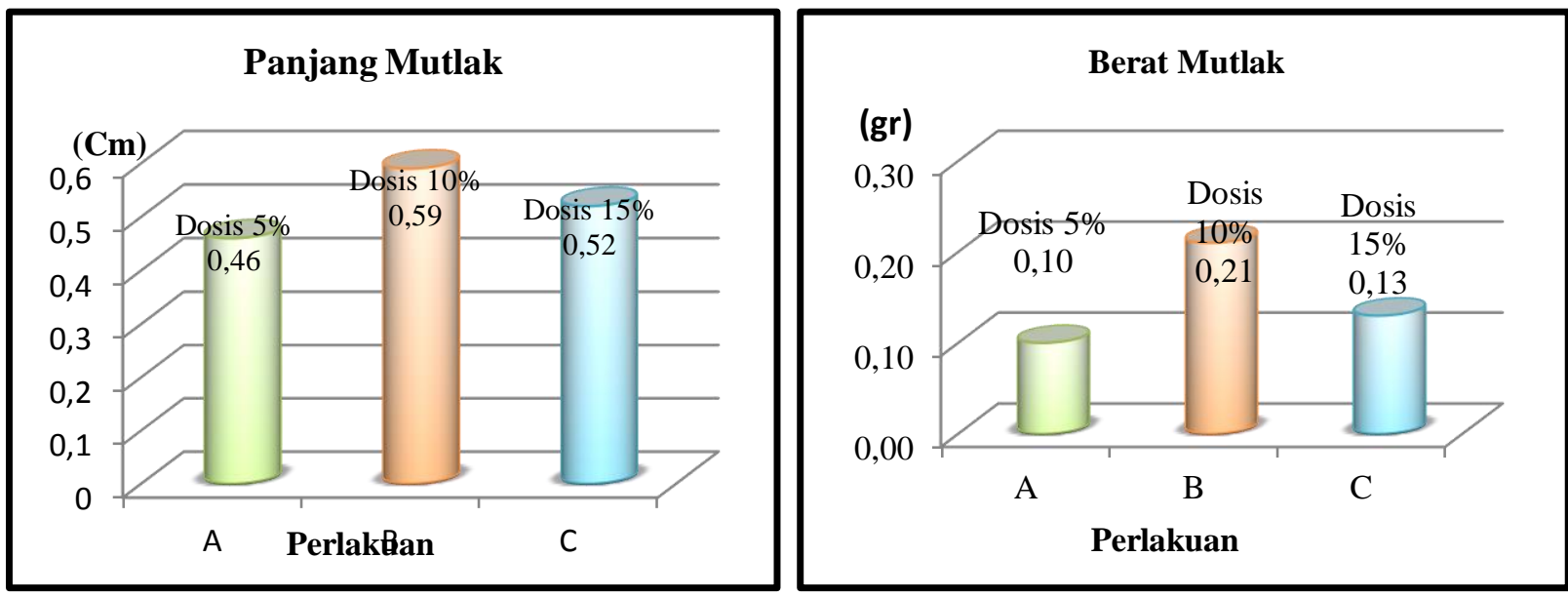

Gambar 1. Grafik pertumbuhan panjang dan berat mutlak benih ikan kerapu bebek (Chromileptes altivelis).

Gambar 1 menunjukkan juga berat mutlak ikan kerapu. Perbedaan tingkat pemberian pakan yang jumlahnya $10 \%$, dari total bobot badan benih ikan dapat termanfaatkan seefisien mungkin untuk perumbuhan benih. Tetapi pemberian pakan yang 5\% dari total bobot badan benih ikan tidak efektif untuk pertumbuhan benih ikan kerapu bebek. Hal ini sesuai dengan pernyataan Kordi, M. Ghufran (2011), bahwa tingkat pemberian pakan yang jumlahnya $10 \%$ dari total bobot badan benih ikan menunjukkan bahwa jumlah pakan yang diberikan semakin efektif untuk pertumbuhan benih, sebaliknya jumlah pakan yang 5\% dari total bobot badan benih ikan menunjukkan bahwa jumlah pakan yang diberikan semakin tidak efektif untuk pertumbuhan benih ikan.

\section{Pertumbuhan Harian}

Laju pertumbuhan harian panjang dan berat benih ikan kerapu bebek (Chromileptes altivelis) selama 28 hari dengan menggunakan tiga perlakuan yakni perlakuan A (Dosis 5\%), perlakuan B $(10 \%)$ dan perlakuan C (Dosis 15\%), dapat di lihat pada Tabel 1. Melianawati, dan Suwirya, (2010), bahwa tingkat pemberian pakan yang optimum bagi benih ikan kerapu bebek adalah 10\%, karena pada tingkat pemberian pakan tersebut terjadi pertumbuhan, baik pada berat dan panjang benih. Peningkatan tingkat pemberian pakan tidak dapat memacu pertumbuhan benih ikan kerapu bebek. Hal ini dapat diasumsikan bahwa tingkat pemberian pakan sebesar $10 \%$ sudah sesuai dengan kapasitas lambung dan kemampuan cerna benih sehingga dapat menghasilkan pertumbuhan benih yang optimal.

Tabel 1. Laju pertumbuhan rata-rata harian benih ikan kerapu bebek (Chromileptes altivelis) selama 28 hari.

\begin{tabular}{lcc}
\hline \multirow{2}{*}{ Perlakuan } & \multicolumn{2}{c}{ Rata-rata } \\
\cline { 2 - 3 } & $\begin{array}{c}\text { Panjang } \\
(\mathrm{cm})\end{array}$ & Berat (gram) \\
\hline A (Dosis 5\%) & 0,016 & 0.004 \\
B (Dosis 10\%) & 0,021 & 0.008 \\
C (Dosis 15\%) & 0,019 & 0.005 \\
\hline
\end{tabular}

\section{Kelangsungan Hidup Benih Ikan Kerapu Bebek (Chromileptes altivelis)}

Dari pengamatan terhadap tingkat kelangsungan hidup benih ikan kerapu bebek selama penelitian yang menggunakan dosis pakan yang berbeda dapat di lihat pada Gambar 2. Selama pemeliharaan, tingkat kelangsungan hidup (Survival rate) yang diperoleh pada perlakuan A perlakuan B dan perlakuan $\mathrm{C}$ sangat baik yaitu $100 \%$, hal ini disebabkan kualitas air yang cukup baik, pakan yang cukup sehingga tidak terjadi kanibalisme hal ini membuat kelangsungan hidup ikan kerapu bebek (Chromileptes altivelis) sangat baik. Menurut Cahyoko, et al., (2009), bahwa pakan yang mempunyai nutrisi yang baik sangat berperan dalam mempertahankan kelangsungan hidup dan mempercepat pertumbuhan ikan. 


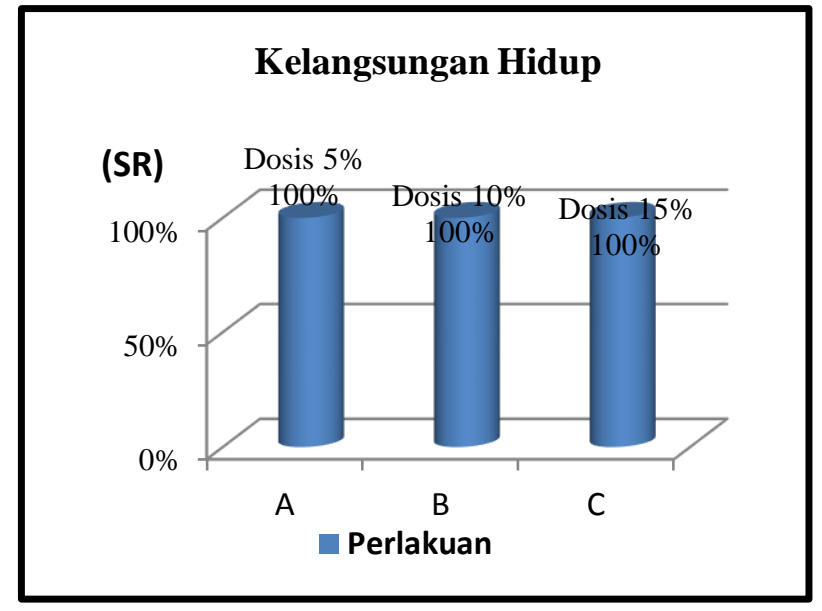

Gambar 4. Grafik kelangsungan hidup benih ikan kerapu bebek (Chromileptes altivelis)

\section{Kualitas Air}

Hasil pengukuran kualitas air selama pemeliharaan benih ikan kerapu bebek (Chromileptes altivelis) menunjukkan bahwa kisaran yang diperoleh masih berada pada batas toleransi bagi kehidupan benih ikan kerapu bebek. Hasil pengukuran kualitas air dapat di lihat pada Tabel 2. Menurut Kordi (2002) dalam Cahyoko, et al., (2009), bahwa suhu yang ideal bagi kehidupan ikan kerapu bebek adalah $27-32{ }^{\circ} \mathrm{C}, \mathrm{pH}$ untuk ikan kerapu bebek yang paling baik yaitu 7,6-8,0 yang merupakan kisaran $\mathrm{pH}$ air laut, dan Oksigen terlarut (DO) pada pemeliharaan ikan kerapu bebek kandungan oksigen terlarut optimal tidak boleh kurang dari $4 \mathrm{mg} / \mathrm{l}$. Dengan demikian suhu kisaran antara $30{ }^{\circ} \mathrm{C}, \mathrm{pH}$ kisaran 6,20, dan oksigen terlarut (DO) 7,5 $\mathrm{mg} / \mathrm{l}$ sudah memenuhi syarat untuk pemeliharaan ikan kerapu bebek. Sedangkan menurut Akbar dan Sudaryanto (2001) dalam Cahyoko, et al., (2009), menyatakan bahwa ikan kerapu bebek pada umumnya menyukai salinitas antara 30-35 ppt. Dengan demikian salinitas dengan kisaran 34,9 ppt sudah sesuai untuk pemeliharaan ikan kerapu bebek.

Tabel 2. Tabel kualitas air selama penelitian

\begin{tabular}{|c|c|c|c|c|c|c|}
\hline \multirow[b]{2}{*}{ No } & \multirow[b]{2}{*}{ Parameter } & \multicolumn{5}{|c|}{ Perlakuan } \\
\hline & & $\begin{array}{c}\text { Minggu } \\
0\end{array}$ & $\begin{array}{c}\text { Minggu } \\
1\end{array}$ & $\begin{array}{c}\text { Minggu } \\
2\end{array}$ & $\begin{array}{c}\text { Minggu } \\
3\end{array}$ & ${ }_{4}^{\text {Minggu }}$ \\
\hline 1 & Suhu $\left({ }^{\circ} \mathrm{C}\right)$ & 30 & 30 & 30 & 30 & 30 \\
\hline 2 & $\begin{array}{l}\text { Salintas } \\
\text { (ppt) }\end{array}$ & 34,9 & 34,9 & 34,9 & 34,9 & 34,9 \\
\hline 3 & $\mathrm{pH}$ & 6,20 & 6,20 & 6,20 & 6,20 & 6,2 \\
\hline 4 & $\begin{array}{l}\mathrm{DO} \\
(\mathrm{mg} / \mathrm{l})\end{array}$ & 7,5 & 7,5 & 7,5 & 7,5 & 7,5 \\
\hline
\end{tabular}

\section{KESIMPULAN}

Berdasarkan hasil penelitian pengaruh pemberian dosis pakan otohime yang berbeda terhadap pertumbuhan benih ikan kerapu bebek (Chromileptes altivelis) dapat disimpulkan bahwa; 1) Dosis pakan otohime yang berbeda berpengaruh terhadap pertumbuhan panjang dan berat benih ikan kerapu bebek (Chromileptes altivelis). 2) Perlakuan B (Dosis 10\%), menunjukkan pertumbuhan yang terbaik terhadap pertumbuhan benih ikan kerapu bebek (Chromileptes altivelis).

\section{DAFTAR PUSTAKA}

Akbar, S dan Sudaryanto. 2001. Pembenihan dan Pembesaran Kerapu Bebek. Penebar Swadaya. Jakarta.

Cahyoko, Y. Agustono, Sari, W. P. 2009. Pemberian Pakan Dengan Energi Yang Berbeda Terhadap Pertumbuhan Benih Ikan Kerapu Tikus (Chromileptes altivelis). Jurnal Ilmiah Perikanan dan Kelautan. (Diakses Tanggal 27 April 2013).http://journal.unair.ac.id/filerPDF/ Pemberian\%20pakan\%20\%5D.pdf

Cholik, F, Ateng G. J, R.P. Purnomo dan Ahmad, Z. 2005. Akuakultur Tumpuan Harapan Masa Depan. Masyarakat Perikanan Nusantara dan Taman Akuarium Air Tawar.

Kordi, M. Ghufran H. 2002. Usaha Pembesaran Ikan Kerapu Di Tambak. Kanisius. Jakarta.

Kordi, M. Ghufran H. 2011. Buku Pintar Budidaya 32 Ikan Laut Ekonomis. Lily Publisher. Yogyakarta.

Madinawati, 2011. Pemberian Pakan Yang Berbeda Terhadap Pertumbuhan dan Kelangsungan Hidup Benih Ikan Lele Dumbo (Clarias gariepinus). http://www.scribd.com/doc/110685556/ 113-387-1-PB

Melianawati, R. Suwirya, K. 2010. Optimasi Tingkat Pemberian Pakan Terhadap Benih Kerapu Sunu (Plectropomus 
leopardus). Prosiding Forum Inovasi Teknologi Akuakultur.

Puja, Y, Evalawati dan Syamsul, A. 2001. Pembesaran Kerapu macan dan Kerapu Tikus di Karamba Jaring Apung. Balai Budidaya Laut Lampung.

Taufik, D. J, 2009. Faktor-faktor yang Mempengaruhi Pertambahan Berat Badan Unggas. Jurnal Urip Santoso (Diakses Tanggal 27 April2013).http://uripsantoso.wordpress. com/2009/11/06/

Widyanto, 2013. Pengaruh Padat Tebar Terhadap Pertumbuhan Benih Ikan Kerapu Macan (Epinephelus fuscoguttatus) Di Balai Benih Ikan Pantai (BBIP) Lamu Provinsi Gorontalo (Skripsi). Program Studi Budidaya Perairan Fakultas Ilmu-Ilmu Pertanian Universitas Negeri Gorontalo. 